\title{
Article
}

Mycosphere

Doi 10.5943/mycosphere/8/4/5

Copyright (C) Guizhou Academy of Agricultural Sciences

\section{Ectomycorrhizal fungal communities associated with Quercus dentata in a coastal broadleaf forest}

\author{
Arai $\mathbf{H}^{1}$, Tamai $\mathbf{Y}^{1}$, Yajima $\mathbf{T}^{1}$, Obase $\mathrm{K}^{2}$ and Miyamoto $\mathrm{T}^{1}$ \\ ${ }^{1}$ Laboratory of Forest Resource Biology, Graduate School of Agriculture, Hokkaido University \\ N-9, W-9, kita-ku, Sapporo, Hokkaido, 060-8589 Japan \\ ${ }^{2}$ Forestry and Forest Products Research Institute, 1 Matsunosato, Tsukuba, Ibaraki, 305-8687 Japan
}

Arai H, Tamai Y, Yajima T, Obase K, Miyamoto T 2017 - Ectomycorrhizal fungal communities associated with Quercus dentata in a coastal broadleaf forest. Mycosphere 8(4), 561-567, Doi $10.5943 /$ mycosphere/8/4/5

\begin{abstract}
Coastal forests are exposed to high salinity and drought stress, and plant growth is restricted under such harsh conditions. Quercus dentata is one of the most common species in coastal forests in northern Japan. We investigated the changing vegetation in a coastal forest, shoreline to inland, and examined the ectomycorrhizal (ECM) fungal communities associated with $Q$. dentata. We aimed to determine whether the ECM changes corresponded with the changes in vegetation. More than $300 \mathrm{~m}$ inland, broadleaf trees such as $Q$. dentata were dominant. An almost pure $Q$. dentata stand was formed in the area closest to the shoreline. By contrast, as the forest moved inland, the occurrence of other tree species increased and the density of $Q$. dentata gradually decreased, respectively. In the areas that were furthest inland, $Q$. dentata, $Q$. crispula, Acer mono, and Tilia japonica were equally dominant. Five sampling plots $(20 \mathrm{~m} \times 20 \mathrm{~m}$, each) were set up in the forest $100 \mathrm{~m}$ apart, and soil cores (including the fine roots of $Q$. dentata) were sampled in each plot. The total ECM colonization rate was > 98\% in each sampling plot. Morphological characterization and DNA sequencing of the root tips identified six taxa (Tomentella sp., Russula spp., Tricholoma sp., Hebeloma sp. and Boletales sp.). Tomentella sp. was relatively abundant near the shoreline and its abundance decreased as the density of $Q$. dentata decreased inland. Conversely, Russula sp. increased as the forest moved inland.
\end{abstract}

Keywords - coastal forest - ectomycorrhizal fungi - Quercus dentata - vegetation

\section{Introduction}

Coastal areas are exposed to high salinity and drought stress, and plant growth is restricted under such harsh conditions. Therefore, coastal vegetation is different from inland vegetation, with plant species tolerant to salinity and drought stress dominating near the shoreline. Plant species that are relatively less tolerant to these stresses dominate in inland forests. The factors underlying the formation of coastal forests remain unclear, and although past reports focus on the aboveground features, such as atmospheric salinity (Yura \& Ogura 2006), underground symbioses may also determine the composition of the forest vegetation.

Ectomycorrhizal (ECM) fungi are important symbionts of plant roots of the dominant vegetation in boreal and temperate forests that includes Pinaceae, Betulaceae and Fagaceae (Smith \& Read 1997; Van der Heijden et al. 2008). The ECM fungi typically inhabit forest soils and increase the plant uptake of soil water and nutrients to form an ECM network (Smith \& Read 
1997). These effects differ between fungal species (Baxter \& Dighton 2001; Lehto \& Zwiazek 2011). Moreover, different forest types support different ECM fungal communities (Smith \& Read 1997).

The oak Quercus dentata (family Fagaceae), which is tolerant to salinity and drought, is one of the most common tree species of the coastal forests in Hokkaido, northern Japan. The fine roots of $Q$. dentata are covered with ECM fungi. From the eastern Asian coastal forests southward to temperate areas, the dominant tree species are typically Pinus spp., such as black pine, and some reports of the associated ECM fungal communities exist (e.g., Taniguchi et al. 2007; Obase et al. 2009; Matsuda et al. 2009; Aučina et al. 2011). Although coastal forests composed primarily of Quercus sp. are one of the most common forest types in northern Japan, reports on the ECM fungal communities of these forests are not available. In the present study, we investigated the changes in vegetation in a coastal forest, from the shoreline inland, and examined the changes in the ECM fungal communities associated with $Q$. dentata to determine if they corresponded with the changes in vegetation.

\section{Materials and Methods}

\section{Study site}

The study site was the Ishikari broadleaf coastal forest, Hokkaido, northern Japan $\left(\mathrm{N} 43^{\circ} 14^{\prime}\right.$ and $\left.\mathrm{E} 141^{\circ} 19^{\prime}\right)$. The mean annual temperature in the forest is $8.8^{\circ} \mathrm{C}$, and the annual precipitation is $1,259.5 \mathrm{~mm}$. The forest extends a few tens $\mathrm{km}$ along the shoreline and, at most, 600 $\mathrm{m}$ inland from the shoreline. The soil is sandy and covered with a layer of plant litter that is a few centimeters thick. The stand was primarily composed of $Q$. dentata and other broadleaf tree species that grew wild Sasa senanensis was dominant on the forest floor.

\section{Vegetation and soil salinity survey}

The vegetation and soil salinity were characterized to identify the differences between the shoreline and inland areas before the assessment of ECM colonization status. The survey was conducted from the shoreline inland, within a $5 \mathrm{~m}$ wide belt. The dominant tree species were evaluated for the percentage of basal area every $100 \mathrm{~m}$. The soil salinity was measured every $100 \mathrm{~m}$ with an electrical conductivity (EC) meter (Twin Cond conductivity meter B-173, Horiba, Japan).

\section{Sampling and observation of ECM colonization}

Five sample plots $(20 \mathrm{~m} \times 20 \mathrm{~m})$ were set up every $100 \mathrm{~m}$ in the forest. 16 cubic soil samples $(25 \mathrm{~cm} \times 25 \mathrm{~cm} \times 25 \mathrm{~cm})$ containing fine roots of $Q$. dentata were collected from each plot, and samples collected from each plot were combined. Although we could easily identify the roots in the soil samples as Quercus sp. by their external appearance, we could not distinguish the roots of $Q$. dentata from $Q$. crispula, because they were very similar to each other. Identification through DNA analysis was not possible because $Q$. dentata and $Q$. crispula often make hybrids. Because of this, the sampling in mixed forests was limited to areas immediately under and around $Q$. dentata specimens distant from $Q$. crispula trees to avoid the possibility of mixed-species sampling. The samples were stored in plastic bags at $4^{\circ} \mathrm{C}$ until further analysis. The fine roots were separated from the adhering soil by soaking and careful washing with tap water. All roots were observed under a microscope after being cut into $5-10 \mathrm{~cm}$ pieces. The viability of the ECM was assessed based on color, surface texture and the degree of mantle layer development. Non-viable ECM that appeared shrunk, discolored, and brittle were excluded from analyses. ECM fungi from each sample were categorized into morphological groups based on such criteria as the ramification system, the color, shape, texture, organization and the abundance of the emanating hyphae or cystidia, rhizomorphs, and the hyphal arrangement of the mantle surface, according to Agerer (1995) and Ingleby et al. (1990). The total ECM colonization rate and composition ratio of each ECM type were measured to compare the mycorrhizal status between plots. Total ECM colonization rate was calculated as follows: total ECM colonization rate $(\%)=$ (number of $\mathrm{ECM}$ 
root tips)/(total number of root tips). The composition ratio of each ECM type was calculated as follows: ratio of specific ECM type = (number of the particular ECM type $) /($ total number of ECM root tips).

\section{Identification of ECM fungal species}

Two or three root tips were collected for each ECM morphotype, and the DNA was extracted with the DNeasy Plant Mini kit (QIAGEN, USA) according to the manufacturer's instructions. DNA amplification of the internal transcribed spacer (ITS) regions, including the 5.8S rDNA, was performed with a thermal cycler (2720 Thermal Cycler, Applied Biosystems). Because clamp connections were observed in all the ECM samples, the DNA was amplified via nested PCR using Basidiomycetes specific primer sets ITS1OF and ITS4OF (both developed by D. L. Taylor and available online at http://mercury2.iab.uaf.edu/lee taylor/PCR_Primers_Orchid_Fungi.html) before the amplification with universal primers ITS1 (White et. al. 1990) and ITS4 (White et. al. 1990). The amplification was performed with the following program: initial denaturation at $95^{\circ} \mathrm{C}$ for $3 \mathrm{~min}$, followed by 40 cycles of denaturation at $95^{\circ} \mathrm{C}$ for $15 \mathrm{~s}$, annealing at $50^{\circ} \mathrm{C}$ for $40 \mathrm{~s}$, extension at $72^{\circ} \mathrm{C}$ for $40 \mathrm{~s}$, and final extension at $72^{\circ} \mathrm{C}$ for $7 \mathrm{~min}$. The PCR products were analyzed by electrophoresis on $2 \%$ agarose gels and visualized with a UV light transilluminator after staining with EZ-Vision Three DNA Dye and Buffer (AMRESCO, USA). The sequences were compared with those deposited at GenBank database at the DNA Data Bank of Japan (DDBJ: http://www.ddbj.nig.ac.jp/) using the nucleotide-nucleotide basic local alignment search tool algorithm (BLAST). Assignment to taxonomic categories was performed as follows: sequence similarity of more than $97 \%$ signified identification to species level; sequence similarity of 95-97\% equaled identification to genus level; sequence similarity of less than $95 \%$ meant identification to family or order level.

\section{Statistic analyses}

Analysis of variance followed by Tukey's test was used to compare mean soil EC of samples, significance level $p<0.05$. To assess the sufficiency of sampling for each plot, species accumulation curves were generated. The curves were obtained by plotting the means of the total number of the expected species (Sobs, Mao Tau) in pooled samples, after 50 randomizations without replacement, using Estimate S version 8.0.0 (Colwell 2005).

\section{Results}

\section{Vegetation and soil salinity differences between the near shoreline and inland areas}

The area 50-300 $\mathrm{m}$ from the shoreline was dominated by herbs and shrubs, while broadleaf trees, primarily $Q$. dentata, dominated $300 \mathrm{~m}$ and more from the shoreline. Quercus. dentata, Ulmus davidiana, Acer mono, Sorbus alnifolia, Maackia amurensis, Prunus sargentii, Morus bombycis, Kalopanax pictus, Q. crispula and Tilia japonica were observed on the study site. The main tree species that formed a symbiotic association with ECM fungi were Quercus. dentata and $Q$. crispula. An almost pure $Q$. dentata stand formed in the area closest to the shoreline; however, the densities of other tree species increased, while the density of $Q$. dentata gradually decreased, as the forest moved inland, accordingly (Table 1). The EC values (mean \pm standard deviation) ranged from $19.33 \pm 4.04$ to $47.67 \pm 13.32 \mu \mathrm{S} / \mathrm{cm}$ and were higher near the shoreline, in the pure $Q$. dentata stand (Table 2).

\section{ECM colonization status and identification from roots of $Q$. dentata}

A total of 50,258 ECM root tips $(13,752,14,610,9,556,5,576$ and 6,764 root tips for the 300, 400, 500, 600 and $700 \mathrm{~m}$ plots, respectively) were examined. The ECM colonization rates were more than $98 \%$ in all sample plots (Table 3). Six morphotypes of ECM root tips were characterized (Fig. 1). The species accumulation curves for ECM fungi in each sample plot tended to level off, which indicated that most ECM fungal taxa have been detected in the sample plots (Fig. 2). 
Table 1 The observed tree species and the percentage of basal area (\%) every $100 \mathrm{~m}$ from the shoreline on the study site

\begin{tabular}{llllll}
\hline Distance from shoreline (m) & $300-400$ & $400-500$ & $500-600$ & $600-700$ & $700-800$ \\
\hline Quercus dentata & 94.0 & 87.7 & 64.0 & 54.9 & 17.3 \\
Acer mono & 1.3 & 8.9 & 12.4 & 16.5 & 19.6 \\
Ulmus davidiana & 4.7 & & & & 3.4 \\
Sorbus alnifolia & & 1.8 & 0.9 & 2.4 & 3.7 \\
Maakia amurensis & & 0.8 & 6.0 & 4.5 & 5.3 \\
Prunus sargentii & & 0.4 & 0.8 & 1.9 & \\
Morus bombycis & 0.4 & & 2.1 & \\
Kalapanax pictus & & 12.1 & 10.3 & 11.3 \\
Quercus crispula & & 3.8 & 7.4 & 17.1 \\
Tilia japonica & & & & 22.3 \\
\hline
\end{tabular}

Table 2 Soil EC every $100 \mathrm{~m}$ from the shoreline on the study site (values are means $\pm \mathrm{SD}, \mathrm{n}=3$ ). The letters indicate significant differences at $p<0.05$ (Tukey's test).

\begin{tabular}{lllllllllllllllll}
\hline Distance from shoreline $(\mathrm{m})$ & 100 & & 200 & & 300 & 400 & 500 & 600 & 700 & 800 & \\
\hline \multirow{2}{*}{$\mathrm{EC}(\mu \mathrm{S} / \mathrm{cm})$} & 47.7 & \pm & 37.7 & \pm & 21.3 & \pm & 46.0 & \pm & 23.7 & \pm & 21.3 & \pm & 19.3 & \pm & 27.3 & \pm \\
& $13.3 \mathrm{a}$ & $3.8 \mathrm{~b}$ & & $2.5 \mathrm{c}$ & $12.1 \mathrm{a}$ & $3.1 \mathrm{c}$ & & $1.5 \mathrm{c}$ & & $4.0 \mathrm{c}$ & & $1.5 \mathrm{c}$ & \\
\hline
\end{tabular}

Table 3 ECM colonization rates (\%) of $Q$. dentata in sample plots on the study site

\begin{tabular}{llllll}
\hline Distance from shoreline $(\mathrm{m})$ & 300 & 400 & 500 & 600 & 700 \\
\hline ECM colonization rate (\%) & 98.8 & 98.1 & 99.8 & 99.2 & 99.7 \\
\hline
\end{tabular}

Table 4 Identification of ECM fungi from the fine roots of $Q$. dentata from the study site

\begin{tabular}{llll}
\hline Identification & Accession no. & Closest match & Similarity \\
\hline Tomentella sp. & AB979726 & Tomentella sp. AF272912 & $534 / 556(96 \%)$ \\
Russula sp. & AB979725 & Russula heterophylla DQ422006 & $572 / 589(97 \%)$ \\
Russulaceae sp. & AB979729 & Russula heterophylla DQ422006 & $553 / 598(92 \%)$ \\
Tricholoma sp. & AB979730 & Tricholoma album AF241516 & $564 / 589(95 \%)$ \\
Hebeloma sp. & AB979728 & Hebeloma sp. FJ168594 & $371 / 383(96 \%)$ \\
Boletales sp. & AB979727 & Xerocomus subtomentosus JQ967281 & $489 / 564(86 \%)$ \\
\hline
\end{tabular}

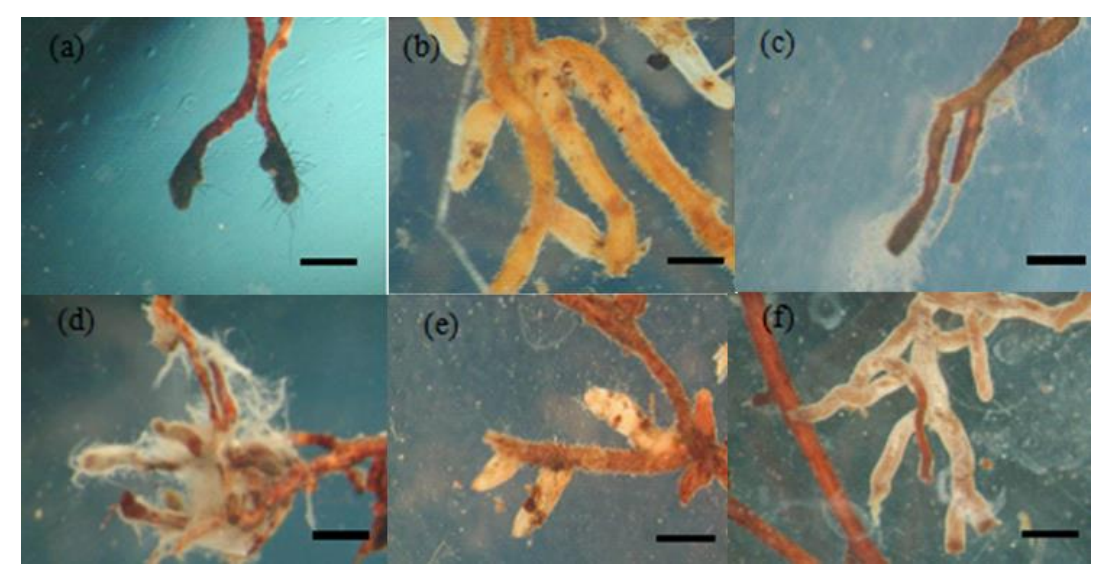

Fig. 1 - The appearance of ECM from fine roots of $Q$. dentata from the study site. (a) Tomentella sp., (b) Russula sp., (c) Russulaceae sp., (d) Tricholoma sp., (e) Hebeloma sp., and (f) Boletales sp. - Bars $=1 \mathrm{~mm}$. 


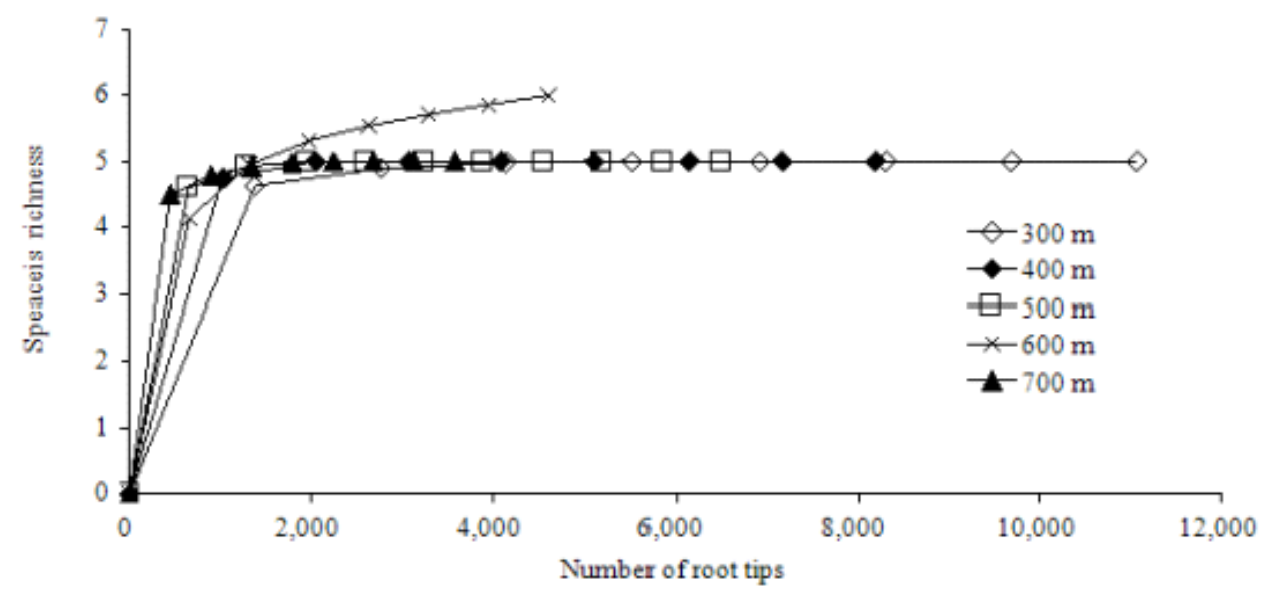

Fig. 2 - Species accumulation curves for ECM fungi of $Q$. dentata in the study site.

\section{Composition of ECM fungi in each sample plot}

The ITS regions were sequenced, with the similarities to sequences deposited in the DDBJ GenBank database ranging from $86 \%$ to $97 \%$ (Table 4). We identified six total taxa. Tomentella sp., Russula sp., Russulaceae sp., Tricholoma sp. and Hebeloma sp. were observed in all sample plots, while the species of Boletales were only observed in the plot $600 \mathrm{~m}$ inland, and their relative abundance was extremely low $(0.1 \%$, Table 5$)$. Tomentella sp. was relatively abundant in the plot near the shoreline but the abundance gradually decreased inland (Table 5). In the $300 \mathrm{~m}$ plot, Russula sp. occurrence frequency was nearly the same as for Tomentella sp., but was higher than Tomentella sp. further inland. The remaining ECM fungal taxa did not show clear associations of abundance with the distance from the shoreline.

Table 5 The relative frequencies (\%) of ECM fungal taxa in study plots on the study site

\begin{tabular}{llllll}
\hline & \multicolumn{2}{l}{ Distance from shoreline $(\mathrm{m})$} & & & \\
& 300 & 400 & 500 & 600 & 700 \\
\hline Tomentella sp. & 39.8 & 23.8 & 14.4 & 11.7 & 12.2 \\
Russula sp. & 39.7 & 73.7 & 68.8 & 66.5 & 65.7 \\
Russulaceae sp. & 10.7 & 0.8 & 7.0 & 11.2 & 10.5 \\
Tricholoma sp. & 9.0 & 0.6 & 3.2 & 1.0 & 3.2 \\
Hebeloma sp. & 0.8 & 1.1 & 6.6 & 9.5 & 8.4 \\
Boletales sp. & & & & 0.1 & \\
\hline
\end{tabular}

\section{Discussion}

In this study, we investigated the ECM fungal communities associated with $Q$. dentata in different stand structures in a coastal broadleaf forest of northern Japan. Aboveground, Q. dentata, which is tolerant to high salinity, was the dominant species nearest the shoreline, where the soil salinity was highest, while the frequency of other tree species increased inland. Underground, we classified the $Q$. dentata ECM fungi from different stand structures into six taxa, using morphological and genetic discrimination. The dominant ECM fungal species were Tomentella sp. and Russula sp. Tomentella sp. was relatively abundant near the shoreline and decreased as the density of $Q$. dentata decreased inland. Conversely, Russula sp. increased as the forest moved inland.

The ECM fungal communities of coastal forests have been examined in some studies. For example, the ECM fungal communities associated with Pinus sp. in eastern Asian coastal forests were investigated, with the dominant fungal species identified as Cenococcum geophilum (Taniguchi et al. 2007; Obase et al. 2009a; Matsuda et al. 2009). Indeed, C. geophilum is the most 
common ECM fungal species in temperate and boreal forests and is often the dominant species in several forest types in addition to pine, such as poplar (Krpata et al. 2008), spruce (Baier et al. 2006) and oak (Valentine et al. 2004; Gebhardt et al. 2007). Moreover, previous reports showed that C. geophilum was salinity (Dixon et. al 1993; Matsuda 2006) and drought tolerant (Pigott 1982; Di Pietro et al. 2007). These characteristics are important for survival in coastal conditions and for forming stands; therefore, C. geophilum is thought to play an important role in the formation of coastal forests. However, we did not find C. geophilum in this study. Instead, the dominant ECM fungal species were Tomentella sp. and Russula sp., which differs from previous reports of the ECM fungal communities associated with pine in a coastal forest. A study by Richard et al. (2011) examined the ECM fungal communities associated with $Q$. ilex in a Mediterranean forest, and found the dominant fungal taxa to be Thelephoraceae and Russulaceae. These fungal taxa are also common in temperate and boreal forests (e.g., Lang et. al 2011; Kranabetter et. al 2011).,Although these fungal taxa are common in various environments and thought to help growth of host plants, few studies of their actual effects on host plants have been conducted. Obase et al. (2009b) studied the effect of the mycorrhizal symbiosis of another Tomentella sp. and Populus maximowiczii seedlings in volcanic debris, and found that this symbiosis promoted the growth of host plants. Nevertheless, because only a few reports exist and conditions differ between studies, whether Tomentella sp. promotes the growth of host plants in a coastal forest remains to be investigated.

We found that the number of ECM fungal taxa in a coastal forest was low compared with inland forests, although our sampling effort was sufficiently robust to identify ECM fungal communities in a coastal forest. Matsuda et al. (2009) proposed that the coastal pine stands developed fewer ECM fungal associations and had simpler community structure than inland forests. The same phenomenon likely occurred in the Quercus sp. stand. The ECM fungal communities of other stands should be characterized to identify the factors that affect the formation of coastal vegetation.

\section{References}

Agerer R. 1995 - Anatomical characteristics of identified ectomycorrhizas: an attempt towards a natural classification. In: Varma AK, Hock B (eds) Mycorrhiza: structure, function, molecular biology and biotechnology. Springer, Berlin, 685-734.

Aučina A, Rudawska, M Leski T, Ryliškis D, Pietras M, Riepšas E. 2011 - Ectomycorrhizal fungal communities on seedlings and conspecific trees of Pinus mugo grown on the coastal dunes of the Curonian Spit in Lithuania. Mycorrhiza 21, 237-245.

Baier R, Ingenhaag J, Blaschke H, Göttlein A, Agerer R. 2006 - Vertical distribution of an ectomycorrhizal community in upper soil horizons of a young Norway spruce (Picea abies [L.] Karst.) stand of the Bavarian Limestone Alps. Mycorrhiza 16, 197-206.

Baxter JW, Dighton J. 2001 - Ectomycorrhizal diversity alters growth and nutrient acquisition of grey birch (Betula populifolia) seedlings in host-symbiont culture conditions, New Phytologist 152, 139-149.

Colwell RK. 2006 - EstimateS: statistical estimation of species richness and shared species from samples. Version 8.0.0. User's guide and application. http://purl.oclc.org/estimates (Online).

Di Pietro M, Churin JL, Garbaye J. 2007 - Differential ability of ectomycorrhizas to survive drying. Mycorrhiza 17,547-550.

Dixon RK, Rao MV, Garg VK. 1993 - Salt stress affects in vitro growth and in situ symbioses of ectomycorrhizal fungi. Mycorrhiza 3, 63-68.

Gebhardt S, Neubert K, Wöllecke J, Münzenberger B, Hüttl RF. 2007 - Ectomycorrhiza communities of red oak (Quercus rubra L.) of different age in the Lusatian lignite mining district, East Germany. Mycorrhiza 17, 279-290.

Ingleby K, Mason PA, Last FT, Fleming LV. 1990 - Identification of ectomycorrhizas. ITE Research publication no. 5. HMSO, London. 
Kranabetter JM, Durall DM, MacKenzie WH. 2011 - Diversity and species distribution of ectomycorrhizal fungi along productivity gradients of a southern boreal forest. Mycorrhiza19, 99-111.

Krpata D, Peintner U, Langer I, Fitz WJ, Schweiger P. 2008 - Ectomycorrhizal communities associated with Populus tremula growing on a heavy metal contaminated site. Mycological Research 112, 1069-1079.

Lehto T, Zwiazek JJ. 2011 - Ectomycorrhizas and water relations of trees: a review, Mycorrhiza 21, 71-90.

Matsuda Y, Noguchi Y, Ito S. 2009 - Ectomycorrhizal fungal community of naturally regenerated Pinus thunbergii seedlings in a coastal pine forest. Journal of Forest Research 14, 335-341.

Matsuda Y, Sugiyama F, Nakanishi K, Ito S. 2006 - Effects of sodium chloride on growth of ectomycorrhizal fungal isolates in culture. Mycoscience 47, 212-217.

Obase K, Cha JY, Lee JK, Lee SY, Lee JH, Chun KW. 2009a - Ectomycorrhizal fungal communities associated with Pinus thunbergii in the eastern coastal pine forests of Korea. Mycorrhiza 20, 39-49.

Obase K, Tamai Y, Yajima T, Miyamoto T. 2009b - Mycorrhizal synthesis of four ectomycorrhizal fungi in potted Populus maximowiczii seedlings. Mycoscience 50, 143-145.

Pigott CD. 1982 - Survaival of mycorrhiza formed by Cenococcum geophilum Fr. in dry soils. New Phytologist 92, 513-517.

Richard F, Roy M, Shahin O, Sthultz C, Duchemin M, Joffre R, Selosse M. 2011 Ectomycorrhizal communities in a Mediterranean forest ecosystem dominated by Quercus ilex: seasonal dynamics and response to drought in the surface organic horizon. Annals of Forest Science 68, 57-68.

Smith SE, Read DJ. 1997 - Mycorrhizal symbiosis, 2nd edition. Academic Press, San Diego.

Taniguchi T, Kanzaki N, Tamai S, Yamanaka N, Futai K. 2007 - Does ectomycorrhizal fungal community structure vary along a Japanese black pine (Pinus thunbergii) to black locust (Robinia pseudoacacia) gradient? New Phytologist 173, 322-334.

Valentine LL, Fiedler TL, Hart AN, Petersen CA, Berninghausen HK, Southworth D. 2004 Diversity of ectomycorrhizas associated with Quercus garryana in southern Oregon. Canadian Journal of Botany 82, 123-135.

Van der Heijden MGA, Bardgett RD, Van Straalen NM. 2008 - The unseen majority: soil microbes as drivers of plant diversity and productivity in terrestrial ecosystems. Ecological Letters 11, 296-310.

White TJ, T Bruns, S Lee, and JW Taylor. 1990 - Amplification and direct sequencing of fungal ribosomal RNA genes for phylogenetics, 315-322. PCR Protocols: A Guide to Methods and Applications, eds. Innis, M.A., DH Gelfand, JJ Sninsky, and TJ White. Academic Press, Inc., New York.

Yura H, Ogura A. 2006 - Sandblasting as a possible factor controlling the distribution of plants on a coastal dune system. Plant Ecology 185, 199-208. 